(C) Каліна К. Є., Штефан Л. А. 2019

https://orcid.org/0000-0002-4252-7690

https://orcid.org/0000-0002-6281-980X

DOI: $10.34142 / 23128046.2019 .46 .05$

К. С. Каліна, Л. А. Штефан

\title{
МЕТОДОЛОГІЧНІ ПІДХОДИ ДО ДОСЛІДЖЕННЯ ПРОБЛЕМ ПЕДАГОГІЧНОЇ ТЕОРІЇ І ПРАКТИКИ
}

У статті аналізуються методологічні підходи до дослідження проблем педагогічної теорії та практики. 3'ясовано, що питанням вивчення методологічних засад педагогічної науки присвятили свої праці В. Галузинський, Б. Гершунський, С. Гончаренко, В. Гмурман, М. Данилов, М. Свтух, В. Крисько, В. Лутай, М. Нікандров, П. Підкасистий, М. Ярмаченко та ін. дослідники. Методологічні підходи до педагогіки як науки визначені й у прачях зарубіжних (Е. Дюркгейм, Д. Дьюі, П. Наторп та деяких ін.) учених.

Аналіз зазначених праць свідчить про необхідність розрізняти методологію в широкому і вузькому значення. У широкому розумінні слова це вчення про структуру, логічну організацію, методи та засоби діяльності. У вузькому - вчення про принщипи побудови, форми та способи науковопізнавальної діяльності. Установлено, щзо до методологічних засад педагогічної науки в широкому значенні належать різні підходи антропологічний, аксіологічний, системний, особистісно-діяльнісний, культурологічний, етнопедагогічний, компетентнісний та деякі ін.

У науково-педагогічних джерелах найбільш поширеною є класифікачія рівнів методології, запропонована Е. Юдіним, котра включає: філософський, загальнонауковий (об'єкт, предмет, мета, завдання, гіпотеза дослідження та ін.), конкретнонауковий (сукупність методів та приниипів дослідження, що використовуються в даній научі) та технологічний рівні.

Доведено, що у сучасній науці існують різні підходи до класифікаиії методів. Зокрема, за ступенем загальності методи поділяються на: всезагальні (філософські), загальнонаукові - статистичні, формалізовані та математичні, спеціальні. За метою наукової діяльності методи бувають: фундаментальні (історико-логічний, логічний та порівняльний), прикладні (збір та опрачювання інформації, педагогічний експеримент, педагогічна діагностика). Проте, арсенал методів педагогічної науки є більш широким, тому щзо вони $\epsilon$ інтеграцією методів, накопичених у системі наук про людину. Слід зауважити, щзо иі методи не можна переносити механічно. Вони матимуть ефект і користь для педагогічної теорії та практики тільки тоді, коли будуть пристосовані до ї̈ змісту. 
Ключові слова: метод, підхід, методологія, педагогічна наука, теорія, практика.

Kalina K. Ye., Shtefan L. A. Methodological approaches to the research of problems of pedagogical theory and practice. The article analyzes the methodological approaches to the research of problems of pedagogical theory and practice. It has been found out that V. Haluzynskyi, B. Hershunskyi, S. Honcharenko, V. Hmurman, M. Danilov, M. Yevtukh, V. Krysko, V. Lutai, M. Nikandrov, P. Pidkasystyi, M. Yarmachenko and other researchers devoted their works to the problems of studying methodological principles of the pedagogical science. Methodological approaches to pedagogy as a science are also defined in the works of foreign scholars (E. Durkheim, J. Dewey, P. Natorp, and some others).

The analysis of these works shows the need to distinguish between the methodology in a broad and narrow sense. The broad sense of the word is the doctrine of the structure, logical organization, methods and means of the activity. The narrow one is the doctrine of the construction principles, forms and ways of the scientific and cognitive activity. It has been established that the methodological foundations of the pedagogical science in the broad sense include different approaches. They are anthropological, axiological, systemic, person-activity, cultural, ethnopedagogical, competence and some others.

In scientific and pedagogical sources, the classification of methodology levels by E. Yudin is the most common. It includes philosophical; general scientific (object, subject, purpose, task, research hypothesis, etc.); specifically scientific (the totality of methods and principles of the research used in this science) and technological levels.

It has been proved that in modern science there are different approaches to the classification of methods. In particular, for the degree of generality methods are divided into: general (philosophical); general scientific - statistical, formalized and mathematical; special. For the purpose of the scientific activity, the methods are: fundamental (historical-logical, logical and comparative); applied (collection and processing of information, pedagogical experiment, pedagogical diagnostics). However, the arsenal of methods of the pedagogical science is wide, because they are the integration of methods accumulated in the system of human sciences. It should be noted that these methods cannot be implemented mechanically. They will bring the effect and benefits for the pedagogical theory and practice only when adapted to its content.

Keywords: method, approach, methodology, pedagogical science, theory, practice.

Вступ. Провідна роль у з'ясуванні сутності педагогіки як науки належить методології. Як відзначають фахівці, єдиного визначення методології не існує і бути не може. «Серед кола питань, з якими доводиться 
мати справу педагогу, - наголошує П. Підкасистий, - «методологія»є одним iз найневизначеніших, багатозначних i навіть дискусійних» (Pidkasistyi, 1998). Методологія у буквальному розумінні - наука про метод пізнання.

Питанням вивчення методологічних засад педагогічної науки присвятили свої дослідження В. Галузинський, Б. Гершунський, С. Гончаренко, В. Гмурман, М. Данилов, М. Свтух, В. Крисько, В. Лутай, M. Нікандров, П. Підкасистий, М. Ярмаченко та ін. дослідники. Методологічні підходи до педагогіки як науки визначені й у працях зарубіжних (Е. Дюркгейм, Д. Дьюі, П. Наторп та деяких ін.) учених.

Мета та завдання. Визначити провідні методологічні підходи та методи наукового пізнання, які доцільно використовувати при вивченні питань педагогічної теорії та практики.

Методи дослідження. На різних етапах наукового пошуку використано комплекс методів, адекватних природі феномена, що вивчався, а саме: теоретичні (загальнонаукові методи - аналітичний, історико-зіставний, ретроспективний, історико-генетичний та порівняльний аналіз педагогічної літератури і даних з наукознавства; проблемно-цільовий аналіз законодавчих актів, матеріалів періодичної преси, результатів досліджень антропологічних наук з метою з'ясування рівнів, підходів та методів вивчення проблем педагогічної теорії та практики).

Результати. Аналіз науково-педагогічних праць свідчить про необхідність розрізняти методологію в широкому і вузькому значеннях. У широкому розумінні слова - це вчення про структуру, логічну організацію, методи та засоби діяльності. У вузькому - вчення про принципи побудови, форми та способи науково-пізнавальної діяльності (Yudin, 1978).

До методологічних засад педагогічної науки в широкому значенні насамперед належать різні підходи - антропологічний, аксіологічний, системний, особистісно-діяльнісний, культурологічний, етнопедагогічний, компетентнісний та деякі ін. 
Спираючись на дослідження М. Кагана, системний підхід передбачає взаємозв'язок і взаємозалежність між відносно самостійними (методологічні засади, мета, завдання, зміст, принципи, форми, умови, тенденції розвитку даної науки тощо) та функціональними (проектуючі, гностичні, процесуально-діяльнісні, управлінсько-організаторські) компонентами педагогічної науки. Зазначений підхід забезпечує цілісну єдність між сутністю педагогічної теорії і змістом педагогічної діяльності. Звернення до системного підходу дозволяє прогнозувати i проектувати подальший розвиток педагогічної науки та зіставляти його наслідки 3 вихідним філософським задумом.

«Предметний аспект системного дослідження, - наголошує М. Каган, передбачає розв'язання двох взаємопов'язаних завдань: по-перше, з'ясування, із яких елементів (компонентів, підсистем) складається система, що вивчається, i, по-друге, - визначення того, як ці елементи між собою пов’язані» (Kahan, 1991).

Антропологічний підхід, у свою чергу, вимагає обов'язкове врахування в педагогіці знань інших наук про людину.

Діяльнісний підхід або особистісно-діяльнісний (Ю. Бабанський), пов’язаний із організацією діяльності об’єкта педагогічного впливу таким чином, щоб він був активним суб'єктом розв'язання власних проблем, спілкування, праці, вибору змісту і форм педагогічної роботи. Це стосується і педагога, для якого зазначена діяльність не догма, а творча праця, що передбачає вибір конкретного змісту, форм, методів та прийомів відповідно до потреб суб’ єктів впливу.

Культурологічний підхід спрямований на те, щоб виховати творчу особистість шляхом засвоєння нею накопичених людством і створення нових цінностей культури. Зазначений підхід вимагає від педагога спеціальних знань про внутрішні процеси духовного світу людини, про закономірності соціокультурного побуту особистості. 
3 культурологічним підходами тісно пов'язаний аксіологічний (ціннісний), котрий передбачає розв'язання завдань гуманізації суспільства.

Етнопедагогічний підхід спрямований на обов'язкове врахування при роботі 3 різними категоріями дитячого населення їх культури, звичаїв, етнічних особливостей у цілому.

Компетентний підхід вимагає з'ясування «провідних компетентностей» педагога - педагогічних, соціологічних, філологічних, історичних, психологічних, медичних, юридичних та деяких ін.

Доцільно звернути увагу на те, що методологічні підходи збагачуються і вдосконалюються разом із розвитком науки і суспільства. Зокрема, група вчених під керівництвом С. Харченка доповнила зазначені підходи комплексним (складова частина системного), полісуб'єктним (відбиває суб'єктно-суб'єктні стосунки), історичним, або історико-логічним та деякими ін. (Mesto zhitelstva - mesto vospitaniia, 1985).

Вивчення методології педагогічної науки в широкому значенні вимагає також 3'ясування рівнів методологічних знань. У науково-педагогічних джерелах найбільш поширеною $є$ класифікація рівнів методології, запропонована Е. Юдіним, котра включає: філософський, загальнонауковий (об’єкт, предмет, мета, завдання, гіпотеза дослідження та ін.), конкретнонауковий (сукупність методів та принципів дослідження, що використовуються в даній науці) та технологічний рівні.

«Компонентами методологічних рівнів, - за переконанням М. Фіцули, - є: загальні закони філософії, зокрема теорії пізнання; закони логіки, закономірності психології; закони і закономірності педагогіки; методи дослідження; вчення класиків педагогіки» (Fitsula, 2000).

Необхідно також звернути увагу на те, що в сучасній науковопедагогічній літературі існують й інші підходи до визначення рівнів методології педагогічної науки. Так, В. Крисько визначає: гносеологічний, що включає загальні наукові підходи до аналізу педагогічних явищ i процесів; світоглядний, який містить положення про фактори формування й 
розвитку дитячої особистості та педагогічну діяльність; науково-змістовний, котрий дозволяе правильно сформулювати закони i закономірності педагогічної науки; логіко-гносеологічний, що забезпечує осмислення предмета й об'єкта педагогіки, визначення іiі наукового апарату, співвідношення педагогічної теорії та практики, з'ясування зв'язків з іншими науками (Krysko, 1999).

На нашу думку, запропонована класифікація є більш вузькою, у порівнянні з попередньою, тому що філософська наука як всезагальна методологія виконує не тільки світоглядну й гносеологічну, а також прогностичну, перетворюючу та деякі інші функції. А запропонований дослідником логіко-гносеологічний рівень $є$ більш детальною конкретизацією загальнонаукового.

Доцільно звернути увагу на те, що тривалий час у науці існувала єдина методологія - марксистсько-ленінська філософія. Ми і сьогодні не заперечуємо важливість окремих положень філософії для з'ясування методологічних питань i поділяємо погляди В. Лутая, котрий визначає філософію як загальнометодологічну основу систематизації «усіх елементів людського світогляду» (Lutai, 1996).

Методологічні положення, крім філософії, розробляються і сучасним людинознавством та суспільствознавством. Висновки психології, соціології, біології, медицини та інших антропологічних наук можуть стати основою для уточнення й розробки категоріального апарату, методів дослідження, побудови концепції педагогіки як науки взагалі та педагогічної діяльності зокрема.

Під методологією педагогіки як науки дослідники розуміють:

- етап розвитку науки (Е. Юдін);

- всебічне вивчення процесів формування особистості (В. Бочарова);

- науку про мету пізнання (Л. Філіппова);

- синтез метатеорії (теорія теорії), методологічних орієнтирів і вчення про метод (В. Гмурман); 
- вчення про метод, науку про побудову людської діяльності

(B. Кемеров);

- шлях дослідження, теорію, вчення про науковий метод пізнання (В. Лозова, А. Троцко);

- вчення про методи пізнання й практичної діяльності (М. Нікандров);

- сукупність філософських ідей (Е. Суханова);

- вивчення питань вибору цілей підготовки людини до життя, концепцій та підходів до пізнання педагогічної дійсності, рушійних сил розвитку освіти, самого предмета педагогіки як науки, методів педагогічного дослідження та ін. (О. Рудницька);

- загальнофілософські принципи, закони та методи пізнання (Л. Міщик);

- систему та спосіб добування знань, а також структуру педагогічної теорії (М. Данилов);

- систему принципів і способів організації та побудови теоретичної і практичної діяльності, а також вчення про цю систему (Н. Важевська, Б. Гершунський);

- наукове підгрунтя тлумачення основних педагогічних явищ i розкриття їх закономірностей (М. Фіцула);

- філософію виховання (В. Семенов);

- вчення про принципи побудови, форми i способи науковопізнавальної діяльності (М. Кратинов, В. Кратинова, С. Харченко, О. Чиж).

Аналіз поглядів науковців дозволяє стверджувати, що в більш загальному визначенні під науковою методологією необхідно розуміти систему підходів до проблеми дослідження.

Особливу значущість, з точки зору предмета нашого вивчення, має підхід до методології педагогічної науки, запропонований В. Загвязинським, котрий включає:

- вчення про структуру та функції педагогічного знання; 
- вихідні, ключові, фундаментальні філософські, загальнонаукові та педагогічні положення (теорії, концепції, гіпотези), які мають методологічне значення;

- вчення про методи педагогічного пізнання (методологія у вузькому значенні слова) (Zahviazinskii, 1982).

Таким чином, кожна наука, щоб відповідати своєму призначенню, повинна бути не тільки упорядкованою системою знань про частину навколишнього світу, але одночасно й методом його пізнання.

Вивчення та узагальнення науково-педагогічних джерел приводить до висновку, що грунтовне вивчення проблема методів наукового пізнання отримала в працях В. Болгаріна, А. Болгарського, В. Гмурмана, М. Кратинова, В. Кратинової, І. Миговича, О. Рудницької, Т. Свістельнікової, I. Філіппової, $\quad$ Л. Філіппової, $\quad$ С. Харченка, О. Чижа та деяких інших дослідників.

Як відомо, метод у загальнофілософському розумінні означає засіб пізнання, спосіб відтворення предмета, що вивчається (Filosofskii entsiklopedicheskii slovar, 1997).

У сучасній науці існують різні підходи до класифікації методів.

Наприклад, за ступенем загальності методи поділяються на:

- всезагальні (філософські);

- загальнонаукові - статистичні, формалізовані та математичні;

- спеціальні (Myhovuch, 1997).

За метою наукової діяльності методи бувають:

- фундаментальні (історико-логічний, логічний та порівняльний);

- прикладні (збір та опрацювання інформації, педагогічний експеримент, педагогічна діагностика) (Myhovuch, 1997).

Проте, як свідчить вивчення науково-педагогічної літератури, найбільшого поширення в педагогічній науці отримав розподіл методів наукового пізнання на теоретичні (аналіз, синтез, абстрагування, ідеалізація, моделювання, індукція, дедукція, узагальнення й ін.) та експериментально- 
емпіричні (спостереження, опитування, тестування, рейтинг, педагогічний експеримент, інтерв'ю, консультування й ін.).

«Безсумніву, подібний розподіл, - справедливо наголошує Н. Важевська, - достатньо умовний, тому що і на емпіричному рівні при отриманні нового знання можуть використовуватися аналіз і синтез, індуктивний висновок та ін.» (Vazhevskaia, 2002).

Вивчення дисертацій, підручників із педагогіки та монографій дозволяє стверджувати, що педагогіка широко використовує як методи теоретичного рівня, що є спільними для всіх наук (аналіз, синтез, порівняння, узагальнення, моделювання ситуацій тощо), так і експериментальні методи (спостереження, бесіда, письмові роздуми, графічні методи, анкета, тести, інтерв’ю, монографічне вивчення сім’ї, соціометричні методики, творчі роботи дітей, експертні оцінки, одержання незалежних характеристик, педагогічний експеримент, метод компетентних суддів та деякі ін.).

Проте, як слушно вважає М. Фіцула, плідному проведенню педагогічних досліджень на сьогоднішній день заважають такі негативні явища як: зосередженість наукових досліджень в адміністративному центрі; ізольованість вітчизняної дослідницької системи від зарубіжної педагогічної науки; слабке матеріально-технічне забезпечення досліджень; недостатнє втілення в шкільну практику їх результатів (Fitsula, 2000).

Обговорення. Проведене дослідження підтверджує результати досліджень вітчизняних і зарубіжних учених щодо доцільності використання методологічних підходів та методів до вивчення проблем педагогічної теорії та практики, а саме: а) застосування антропологічного, аксіологічного, системного, особистісно-діяльнісного, культурологічного, етнопедагогічного, компетентнісного та деякі ін. підходів; б) використання як теоретичних (аналіз, синтез, абстрагування, ідеалізація, моделювання, індукція, дедукція, узагальнення й ін.), так і експериментально-емпіричних (спостереження, опитування, тестування, рейтинг, педагогічний експеримент, інтерв'ю, консультування й ін.) методів наукового пізнання. 
Висновки. Отже, педагогіка, як і будь-яка наука, спирається на методологію в широкому (підходи, рівні) та вузькому (методи вивчення особистості дитини) значеннях. Арсенал методів педагогічної науки є більш широким, тому що вони є інтеграцією методів, накопичених у системі наук про людину. Слід зауважити, що ці методи не можна переносити механічно. Вони матимуть ефект і користь для педагогічної теорії та практики тільки тоді, коли будуть пристосовані до іiі змісту.

\section{ЛІТЕРАТУРА:}

Важевская Н. Е. Гносеологические корни науки в системе школьного образования. Педагогика. 2002. №4. С. 3-9.

Загвязинский В. И. Методология и методика дидактических исследований. М. : Педагогика, 1982. 160 с.

Каган М. С. Системный подход и гуманитарное знание. Л.: Ленинградский университет, 1991. С. 7-76.

Крысько В. Г. Психология и педагогика в схемах и таблицах: Учебно-методическое пособие. Минск : Харвест, 1999. 376 с.

Лутай В. С. Філософія сучасної освіти: Навчальний посібник. К.: Центр «Магістр - S» Творчої спілки вчителів України, 1996. 256 с.

Место жительства - место воспитания. М.: Издательство Политической литературы, 1985. Мигович I. I. Соціальна робота. Вступ до спеціальності. Ужгород, 1997. 190 с.

Педагогика под ред. П. И. Пидкасистого. М.: Педагогичекое общество России, 1998. 640 с. Педагогика под ред. Т. А. Ильиной. М.: Просвещение, 1984. 496 с.

Философский энциклопедический словарь. М., 1997.

Фіцула М. М. Педагогіка: Навчальний посібник для студентів вищих педагогічних закладів освіти. К.: Видавничий центр: «Академія». 2000. 544 с.

Юдин Э. Системный подход и принцип деятельности. М., 1978. С.272.

\section{REFERENCES:}

Filosofskii entsiklopedicheskii slovar (1997). [Philosophical Encyclopedic Dictionary]. Moskva. (in Russian).

Fitsula, M. M. (2000). Pedahohika. [Pedagogy]. Kyiv : Vydavnuchii tsentr «Akademiia». (in Ukranian).

Ilina, T. A. (Ed.) (1984). Pedahohika. [Pedagogy]. Moskva : Prosveshchenie. (in Russian).

Kahan, M. S. (1991). Sistemnyi podkhod i humanitarnoe znanie. [System approach and humanitarian knowledge]. Leninhrad : Leninhradskii universitet. 7-76. (in Russian).

Krysko, V. H. (1999). Psikholohiia i pedahohika v skhemakh I tablitsakh. [Psychology and pedagogy in charts and tables]. Minsk : Kharvest. (in Russian).

Lutai, V. S. (1996). Filosofiia suchasnoi osvity. [Philosophy of modern education]. Kyiv : Tsentr «Mahistr - S» Tvorchoi spilky vchyteliv Ukrainy. (in Ukranian).

Mesto zhitelstva - mesto vospitaniia. (1985). [Place of residence - the place of education]. Moskva : Izdatelstvo Politicheskoi literatury. (in Russian).

Myhovuch, I. I. (1997). Sotsialna robota. [Social work]. Vstup do spetsialnosti. Uzhhorod. (in Ukranian).

Pidkasistyi, P. I. (Ed.) (1998). Pedahohika. [Pedagogy]. Moskva : Pedahohicheskoe obshchestvo Rossii. (in Russian). 
Vazhevskaia, N. Ye. (2002). Hnoseolohicheskie korni nauki v sisteme shkolnoho obrazovaniia. [Epistemological roots of science in the school system]. Pedahohika. 4. 3-9. (in Russian).

Yudin E., (1978). Sistemnyi podkhod i printsip deiatelnosti. [System approach and principle of activity]. Moskva. 272. (in Russian).

Zahviazinskii, V. I. (1982). Metodolohiia i metodika didakticheskikh issledovanii. [Methodology and method of didactic research]. Moskva : Pedahohika. (in Russian).

\begin{tabular}{lll}
\hline \multicolumn{1}{c}{ Інформація про авторів: } & \multicolumn{2}{c}{ Information about the authors: } \\
Каліна Катерина Свгенівна: ORCID: & Kalina Kateryna Yevheniivna: ORCID: \\
httр://orcid.org/0000-0002-4252-7690; & http://orcid.org/0000-0002-4252-7690; PhD in \\
кандидат педагогічних наук, доцент, доцент & Pedagogy, Docent, Associate Professor of \\
кафедри історії педагогіки і порівняльної & History of Pedagogy and Comparative \\
педагогіки Харківського національного & Pedagogy Department, H.S. Skovoroda \\
педагогічного університету імені & Г. C. & Kharkiv National Pedagogical University, \\
Сковороди, вул. Валентинівська, 2, м. & Valentynivska street, 2, Kharkiv, Ukraine, \\
Харків, Україна, 61166 & & 61166 \\
e-mail: kalinahnpu@gmail.com & & e-mail: kalinahnpu@gmail.com
\end{tabular}

Штефан Людмила Андріївна: ORCID: Shtefan Liudmyla Andriivna: ORCID: http://orcid.org/0000-0002-6281-980X; доктор http://orcid.org/0000-0002-6281-980X; Dr. педагогічних наук, професор, завідувач hab. in Pedagogy, Professor, the Head of кафедри історії педагогіки і порівняльної History of Pedagogy and Comparative педагогіки Харківського національного Pedagogy Department, H. S. Skovoroda педагогічного університету імені Г. С. Kharkiv National Pedagogical University, Сковороди, вул. Валентинівська, 2, м. Valentynivska street, 2, Kharkiv, Ukraine Харків, Україна, 61166. e-mail: valeriy.61.sh@gmail.com e-mail: valeriy.61.sh@gmail.com

Цитуйте цю статтю як: Каліна К.Є., Штефан Л.А. Методологічні підходи до дослідження проблем педагогічної теорії і практики. Теорія та методика навчання та виховання. 2019. № 46. C. 59-69. DOI: 10.34142/23128046.2019.46.05

Дата надходження статті до редакції: 13.05.2019

Стаття прийнята до друку: 28.05.2019 